\title{
Water retention and limited larval dispersal: implications for short and long distance dispersers in marine reserves
}

\author{
Mark J. Jessopp*, Rob J. McAllen \\ Department of Zoology, Ecology and Plant Science, University College Cork, Cooperage Building, Distillery Fields, \\ North Mall, Cork, Ireland
}

\begin{abstract}
Although the establishment of reserves is central to marine conservation, previous criteria for the selection of appropriate areas has often been based on historical, aesthetic or logistic factors, resulting in a network of marine reserves that may not effectively meet conservation objectives. Since the dispersal of larvae plays an integral role in determining whether reserves can sustain themselves, whether they can exchange larvae with other protected sites, or whether they can supplement surrounding exploited areas, effective reserve design requires consideration of the processes that may affect larval dispersal. Plankton tows were conducted monthly for 12 mo in a semienclosed marine reserve with long water retention time, in bays with low water retention, and along open coastline, to establish whether larval retention plays an important role in limiting dispersal and creating discrete communities. Significant spatial and temporal differences in larval assemblages were found, with the semi-enclosed reserve, bay, and coast areas showing consistent differences throughout the year. An ANOVA carried out on 11 species identified as differentiating between these areas supported the hypothesis that limited larval exchange was occurring between reserve and nonreserve areas, despite potentially large dispersal distances. Designating bays as reserve areas may provide a means of protecting various species with both long and short dispersal distances, but this must be balanced against the reduced likelihood of closed populations to recover from local catastrophes and the possibility of limited genetic differentiation and inbreeding.
\end{abstract}

KEY WORDS: Marine Protected Areas · MPA · Larval dispersal - Water retention · Lough Hyne · Population sustainability Resale or republication not permitted without written consent of the publisher

\section{INTRODUCTION}

Recently there has been increased interest in the use of Marine Protected Areas (MPAs; also called no-take zones, marine reserves, marine sanctuaries) as tools for the conservation of marine habitats and species, with the resultant designation of many MPAs across the globe. However, designation has often been based on historical, aesthetic or logistic factors, and there have been few tests of explicit hypotheses about the criteria for the design and management of MPAs. This has resulted in a network of protected areas that may not function in a cohesive way to effectively meet conservation objectives.
Fisheries benefits from MPAs to commercially exploited populations immediately outside the protected areas have been well documented (Gell \& Roberts 2003). However, few studies have addressed the crucial role of planktonic dispersing larvae in population sustainability. Large numbers of benthic marine invertebrates have a pelagic larval phase as the primary means of dispersal (Thorson 1946). The nutritional mode (planktotrophic or lecithotrophic), size and shape of larvae provide wide scope for their passive transport across great distances in water currents (Scheltema 1986). During this process, these larval stages are subject to high levels of mortality, resulting 
in increased spatial and temporal variability amongst the surviving larvae available to recruit to a population (Underwood \& Fairweather 1989).

Only when larvae have successfully recruited and grown to maturity, a process involving a certain amount of pre- and post-settlement mortality (Caley et al. 1996), can processes such as competition begin to influence community composition. Therefore, understanding the underlying process of larval supply to suitable settlement locations is fundamental to the study of marine invertebrate communities. While postsettlement mortality has been shown to be the primary determinant of adult distribution of intertidal barnacle species with overlapping distributions (Delany et al. 2003), recent findings from Plymouth, UK, have shown that larval choice at settlement was the more important factor governing adult abundance patterns in the same species (Jenkins 2005). This illustrates the need for increased study in the field of 'supply-side' ecology (Underwood \& Fairweather 1989) to define patterns of marine benthic community dynamics.

To select an optimal reserve for recruitment of the Caribbean spiny lobster, the use of information on larval transport processes, rather than habitat quality or adult density, was most successful (Lipcius et al. 2001). The effectiveness of MPAs is therefore ultimately dependent on reserve configuration and larval dispersal distance. The danger exists that small, isolated reserves will fail to protect long distance dispersers, which can lead to changes in community composition as the reserve provides a greater reproductive advantage to short-distance dispersers (Botsford et al. 2001). Conversely, in a network of smaller MPAs, longer-distance dispersers will have an increased likelihood of dispersing to and settling in other protected areas, while shorter-distance dispersers may still disperse outside of their local reserve, but fail to settle in another, if reserves are not spaced closely enough. For protecting both short and long distance dispersers in a network of coastal marine reserves, individual protected areas should be at least 4 to $6 \mathrm{~km}$ in diameter, and spaced $\leq 20 \mathrm{~km}$ apart (Shanks et al. 2003a). Variation in the spacing between reserves should additionally contribute to more uniform catch levels as a function of larval advection distance (Kaplan 2006). Such a network would be both logistically difficult and costly to implement, but designating protected areas in locations such as bays, where larval dispersal may be limited due to processes such as water retention (Gaines \& Bertness 1992, Archambault \& Bourget 1999), may effectively offer protection for both short and long distance dispersers.

Lough Hyne Marine Nature Reserve, County Cork, Ireland $\left(51^{\circ} 30^{\prime} \mathrm{N} 9^{\circ} 17^{\prime} \mathrm{W}\right)$ was Europe's first designated Marine Reserve, established in 1981. The objec- tive of this study was to investigate the larval assemblages in Lough Hyne, a semi-enclosed marine reserve, and its adjacent coastline, to test the hypothesis that despite potentially large dispersal distances, water retention limits larval dispersal and causes the formation of temporally and spatially distinct larval assemblages.

\section{MATERIALS AND METHODS}

Calculation of flushing time. Lough Hyne Marine Nature Reserve is approximately $1 \mathrm{~km}$ long and $0.5 \mathrm{~km}$ wide and consists of north and south basins approximately $20 \mathrm{~m}$ deep connected by a deeper $(50 \mathrm{~m})$ trough in the western part of the reserve. The reserve is a fully marine inlet with minimal freshwater input and is connected to the ocean through Barloge creek via a shallow (5 $\mathrm{m}$ at high water), narrow $(25 \mathrm{~m}$ ) channel known as the 'rapids', through which tidal exchange occurs. The presence of a rock sill in the rapids modifies the usual semi-diurnal tidal cycle, resulting in an asymmetric tide, with ebb flow lasting approximately twice as long as flood, and a reduced mean spring tidal range of $1 \mathrm{~m}$ inside the lough (Kitching 1987) compared to a $3.7 \mathrm{~m}$ mean spring tidal range at nearby Baltimore harbour, along the adjacent coastline. The flushing time of the reserve is in the region of $41 \mathrm{~d}$ (Johnson et al. 1995). Two small bays approximately 0.5 and $1 \mathrm{~km}$ wide are to the east of Lough Hyne, with depths in the range of 5 to $10 \mathrm{~m}$. Both bays have wide south-facing entrances and the flushing time $\left(T_{\mathrm{E}}\right)$ of these bays was estimated using the tidal prism method, for cases where only basin geometry and tidal range information are available, following Gillibrand (2001):

$$
T_{\mathrm{E}}=0.52 \frac{V+0.7 A R}{0.7 A R} \text { days }
$$

where $V$ is the volume of the bay at low water $\left(10^{6} \mathrm{~m}^{3}\right)$, $A$ is the surface area of the bay at mid tide $\left(\mathrm{km}^{2}\right)$, and $R$ is the mean spring tidal range $(\mathrm{m})$. The mean tidal range in the north-east Atlantic is typically a factor of 0.7 of the mean spring range and is the factor adopted here. The conversion factor of 0.52 accounts for the fact that there are 1.93 semi-diurnal tides $\mathrm{d}^{-1}$. Volume and surface area were calculated by digitising Admiralty charts for the area and generating a 3dimensional model of the bays in GIS software (ArcGIS 8.2). Mean spring tidal range was taken from Baltimore harbour.

The open coastline adjacent to the reserve and bays is very exposed, steep and rocky, with a south-facing aspect and depth in the range of 20 to $23 \mathrm{~m}$. Since there is no enclosed area in which water may be retained, flushing time is assumed to be approximately zero due to high levels of water mixing along the coast. 
Sample collection. Replicate sea surface transects were conducted from a $5 \mathrm{~m}$ rigid inflatable boat in areas a priori defined as Reserve, Bay, and Coast (Fig. 1). Areas were chosen approximately $1 \mathrm{~km}$ apart to ensure sampling independence (after Margalef 1978). In each area, 4 sea surface plankton trawls were conducted, each over approximately $200 \mathrm{~m}$ at an average speed of 1 to 2 knots. Trawls were conducted monthly for $12 \mathrm{mo}$, from September 2004 to August 2005, utilising twin $40 \mathrm{~cm}$ diameter $200 \mu \mathrm{m}$ mesh nets with an attached flowmeter (General Oceanics model 2030R with standard rotor) connected to a buoyed frame, resulting in 8 replicates per area in each month. All trawls were performed during daylight hours, to minimise the effect of diurnal vertical migration of larvae (Rawlinson et al. 2004), and at the same state of tide, i.e. high water at Cobh, County Cork.

Samples were immediately taken back to the laboratory, where they were sieved through a $200 \mu \mathrm{m}$ mesh sieve and the volume of each plankton sample adjusted to $100 \mathrm{ml}$ with $70 \%$ ethanol for preservation, generally within $1 \mathrm{~h}$ of collection. Subsamples in aliquots of 1 to $5 \mathrm{ml}$ were taken using a bulb pipette to yield a sample containing approximately 300 individuals for identification. Planktonic larvae of benthic marine invertebrates were usually identified within

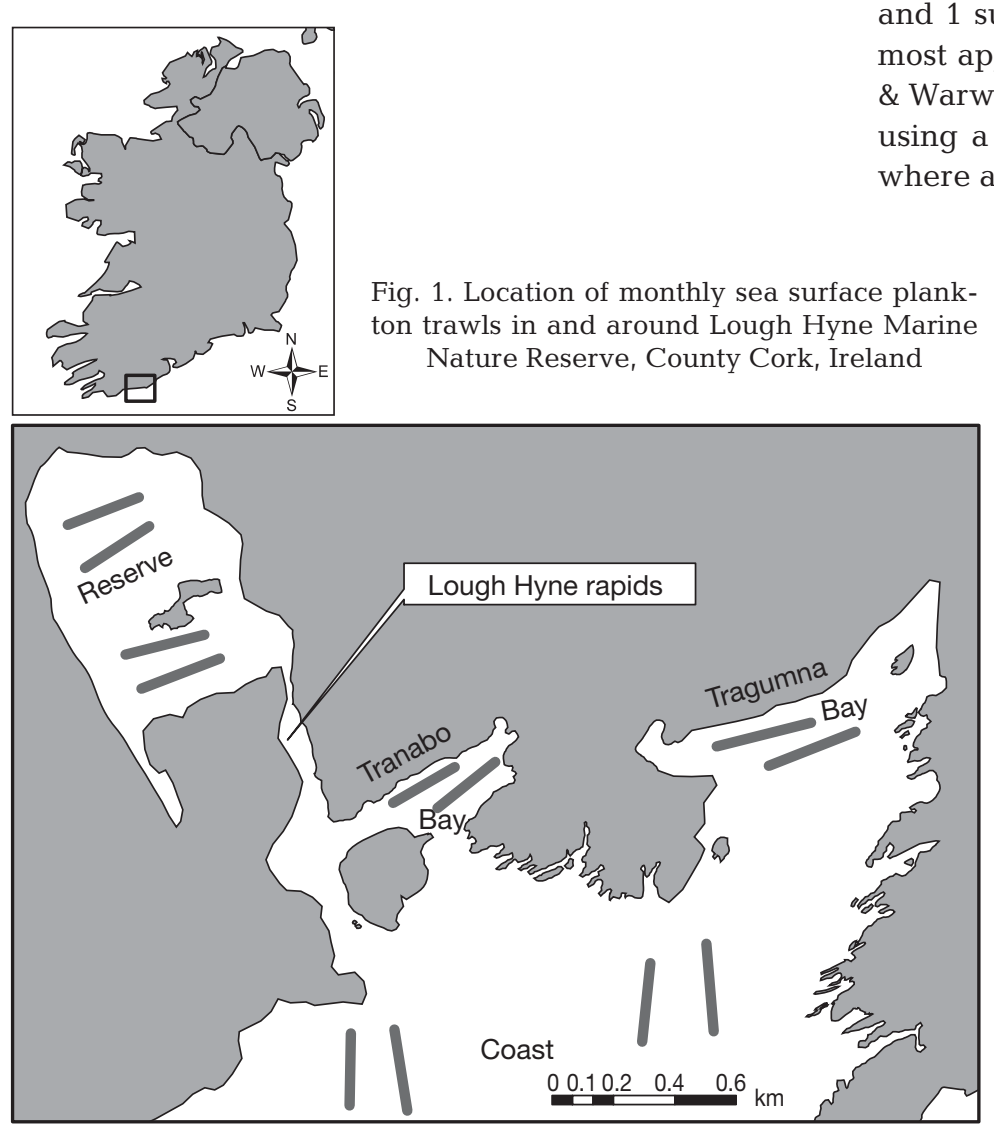

2 wk of preservation to the lowest possible taxonomic level using the current literature. Abundance is given as the number of individuals per cubic metre of sampled water (ind. $\mathrm{m}^{-3}$ ).

Univariate data analysis. Since some samples were dominated by particular species and net clogging may affect the total number of species collected, broad measures of abundance $(N)$ and Shannon-Wiener diversity $\left(H^{\prime}\right)$ were compared to explore their possible effectiveness for monitoring purposes. Species identified as being representative of reserve, coast and bay areas in each season (see subsection 'Multivariate data analysis') were also compared over spatial and temporal scales using ANOVA. Homogeneity of variance within the data was tested using Bartlett's test prior to analysis. For tests on individual species abundance, it is often not possible to transform data to give completely homogeneous variance. Fortunately it is not necessary for a valid ANOVA that variance be precisely equal, or non-normality to be totally removed, as long as gross departures from the parametric assumptions are avoided (Clarke \& Warwick 2001). The appropriate transformation needed to remove large differences in the variance was determined by the slope of the relationship of log (standard deviation) plotted against log (mean). A slope of 0 suggested no transformation was necessary, while slopes of $0.5,0.75$ and 1 suggested square root, 4 th root, and log as the most appropriate transformations respectively (Clarke \& Warwick 2001). Significant results were investigated sing a post hoc test (Tukey's pairwise comparisons) here appropriate.

Multivariate data analysis. Individual species abundance was used to create a Bray-Curtis similarity matrix. In order to determine whether the reserve is representative of the surrounding larval biodiversity, abundance values were square root transformed to highlight potential differences due to high abundance of dominant species, but still to allow some of the less abundant species to influence community structure (Clarke \& Warwick 2001). It was expected that larval assemblages would vary over time, particularly in response to abiotic seasonal cues such as water temperature and hours of daylight, and biotic cues such as food availability and life history characteristics of larvae. Samples were therefore a priori separated into Spring (March to May), Summer (June to August), Autumn (September to November), and Winter (December to February) seasonal groups. Two-dimensional non-metric multidimensional scaling plots were used to visualize the multivariate 
patterns of assemblages (Clarke \& Warwick 2001) and permutational multivariate analysis of variance (PERMANOVA) was used to test for differences in assemblages between areas and seasons on the basis of BrayCurtis similarities between samples (Anderson 2005). The SIMPER routine (PRIMER 6, Plymouth Marine Laboratory) was used to identify species that are representative of each area (reserve, coast, bays), and univariate ANOVA was used to test for spatial and temporal differences in these species.

\section{RESULTS}

The flushing times of Tranabo, Tragumna, and Lough Hyne (Fig. 1) were calculated to be 0.89, 1.86, and $12.49 \mathrm{~d}$, respectively. However, this method assumes that the system is well mixed and that tides exclusively flush the system. While this assumption will be met in Tranabo and Tragumna bays, the restriction of water flow in the rapids causes incomplete mixing of water. In an earlier study, Johnson et al. (1995) accounted for this and derived a more realistic flushing time of $41 \mathrm{~d}$, which is used for comparative purposes in this study.

Filtration efficiency of the plankton nets varied significantly over time $\left(\mathrm{p}<0.001, F_{11,156}=6.49\right)$, with particularly low water volume being sampled in spring and autumn months when phytoplankton blooms contributed markedly to net clogging. The nets filtered on average $19 \mathrm{~m}^{-3}$ of water in each trawl, with many replicates having much lower volume than would have been sampled assuming total filtration efficiency (e.g. $25 \mathrm{~m}^{-3}$ over a $200 \mathrm{~m}$ trawl).

A total of 68 larval taxa were found in net trawls throughout the year. There was a significant interaction between area and season for Shannon-Wiener diversity. While summer and autumn samples had significantly greater diversity than winter and spring samples overall, within-season pairwise comparisons showed that reserve samples had significantly higher diversity than bay and coast samples in spring (Table 1, Fig. 2). Larval abundance $(N)$ varied between areas and seasons with a significant interaction between the 2 factors. Pairwise comparisons showed that the reserve area had greater abundance than coast and bay areas in summer and winter, and bays had greater abundance in autumn. Despite large numbers of barnacle cyprids belonging to the species Chthamalus stellatus in spring bay samples, there were no differences between areas in terms of abundance during spring (Table 1, Fig. 2).

Non-metric multidimensional scaling plots showed a general separation of reserve from bay and coast areas, particularly in autumn and summer, but with a greater degree of overlap in winter and spring (Fig. 3). These groupings were tested using permutational multivariate analysis of variance (PERMANOVA), which showed significant differences in assemblages between areas and seasons, as well as a significant interaction between these factors. Since larval assemblages were expected to differ between all areas, a priori defined pairwise comparisons with Bonferroni correction for 12 comparisons (Reserve vs. Bays, Reserve vs. Coast, Bays vs. Coast for each season, reduced $\propto=0.0042$ ) showed significant differences in assemblages between all areas within seasons ( $p<0.004)$ except bay and coast samples in spring $(p=0.005$, Table 2$)$.

Sixteen species that typify areas in terms of their contribution to the Bray-Curtis similarity between samples within seasons were identified in the SIMPER analysis. Barnacle nauplii of Elminius modestus, Semibalanus balanoides and Chthamalus stellatus were consistently abundant in the reserve area, as were veligers of the gastropod Littorina littorea. Bay and coast areas typically had high abundance of bryozoan cyphonautes larvae of Membranipora membranacea and Electra pilosa, as well as veligers of the bivalves Hiatella spp. and Mytilus spp. Nauplii larvae of Verruca stroemia were common in all areas during all seasons, while Ophiuroid larvae were common in bay and coast areas in autumn. Polychaete trocophores of the family Spionidae were a common component of assemblages in all areas during winter and spring (Table 3, Fig. 4).

Table 1. ANOVA for abundance $(N)$, and Shannon-Wiener diversity $\left(H^{\prime}\right)$ across temporal and spatial scales. Au: autumn; W: winter; Sp: spring; Su: summer; R: reserve; C: coast; B: bay

\begin{tabular}{|c|c|c|c|c|c|c|c|}
\hline \multirow{2}{*}{$\begin{array}{l}\text { Source of } \\
\text { variation }\end{array}$} & df & \multicolumn{3}{|c|}{$\begin{array}{c}\text { MS } \\
N(\log \text { transform })^{\mathrm{a}}\end{array}$} & \multirow{2}{*}{$\begin{array}{c}\text { MS } \\
0.034\end{array}$} & \multirow{2}{*}{$\begin{array}{c}F \\
H^{\mathrm{a}} \\
0.19\end{array}$} & \multirow{2}{*}{$\begin{array}{c}\mathrm{p} \\
0.823\end{array}$} \\
\hline & 2 & 25.04 & 40.78 & $<0.001$ & & & \\
\hline Season & 3 & 98.88 & 161.03 & $<0.001$ & 3.554 & 20.5 & $<0.001$ \\
\hline Area $\times$ Season & 6 & 9.224 & 15.02 & $<0.001$ & 1.228 & 7.08 & $<0.001$ \\
\hline Error & 265 & 0.614 & & & 0.173 & & \\
\hline \multirow[t]{2}{*}{ Total } & 287 & & & & & & \\
\hline & & \multicolumn{3}{|c|}{$\begin{array}{l}\text { Au: } R=C<B \\
\text { W: } R>C=B \\
\text { Sp: } R=C=B \\
\text { Su: } R>C=B\end{array}$} & \multicolumn{3}{|c|}{$\begin{array}{l}\mathrm{Su}=\mathrm{Au}>\mathrm{W}=\mathrm{Sp} \\
\mathrm{Au}: \mathrm{R}=\mathrm{C}=\mathrm{B} \\
\mathrm{W}: \mathrm{R}=\mathrm{C}=\mathrm{B} \\
\mathrm{Sp}: \mathrm{R}>\mathrm{C}=\mathrm{B} \\
\mathrm{Su}: \mathrm{R}=\mathrm{C}=\mathrm{B}\end{array}$} \\
\hline
\end{tabular}



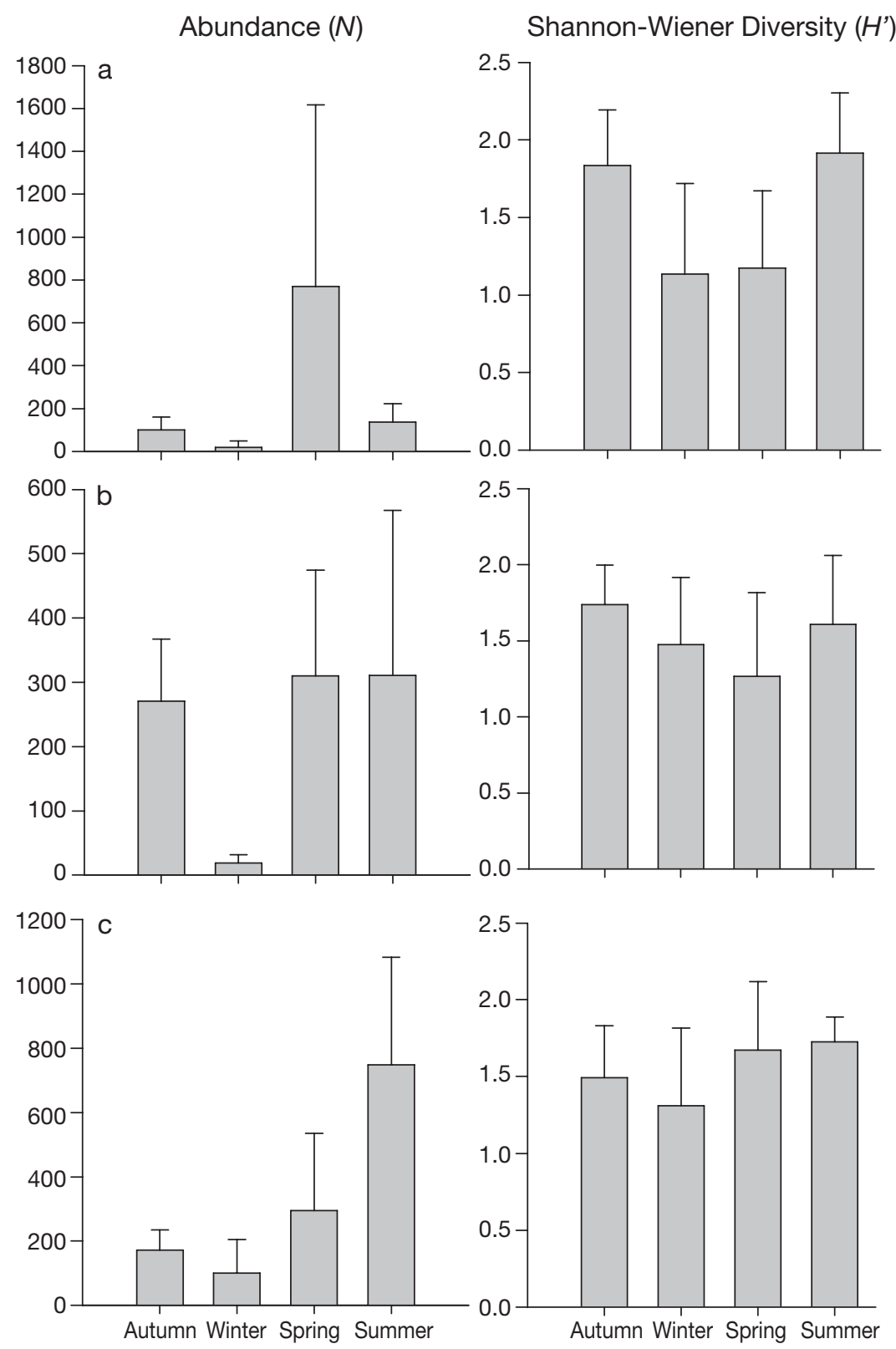

Fig. 2. Seasonal abundance $(N \pm \mathrm{SD})$ and Shannon-Wiener diversity index $\left(H^{\prime}\right.$ $\pm \mathrm{SD}$ ), for (a) bays, (b) coast and (c) reserve. Note different scales for abundance

Univariate ANOVA on species typifying areas revealed spatial and temporal patterns of abundance. No significant difference in abundance was found between areas for Verruca stroemia, Semibalanus balanoides or spionid worm trochophores. Reserve areas had consistently higher abundance of barnacle larvae of Chthamalus stellatus and Elminius modestus, and consistently lower abundance of the bryozoan Membranipora membranacea. Significant interactions were observed between area and season for the remaining species; Mytilus spp. veligers were only more abun- dant in coast samples during autumn, cyphonautes larvae of Electra pilosa were more abundant in coast samples in autumn and spring, and veligers of Littorina littorea were only more abundant in reserve samples during summer and winter. Additionally, the only differences noted in abundance of bivalve veligers of Hiatella spp. and ophiopleuteus larvae of ophiuroids occurred in autumn (Table 4).

\section{DISCUSSION}

The dispersal of larvae plays an integral role in determining whether reserves can sustain themselves, exchange larvae with other protected sites, or supplement surrounding exploited areas. For a network of marine reserves, it has been suggested that reserves be placed at a range of tens of kilometres to ensure adequate connectivity for dispersing larvae (Shanks et al. 2003a). However, to ensure a selfsustaining population, with possible spill-over effects for commercially exploited adult populations with a short dispersal distance, individual reserves should be larger than this dispersal distance.

The ability to differentiate between larval assemblages and to use this information to illustrate the potential of larvae to disperse or be retained locally in reserves requires collection of accurate quantitative data. Net filtration efficiency was shown to vary as a result of net clogging, a factor which means that progressively less water is sampled with trawl duration. It is therefore essential to account for this difference when comparing trawls across temporal and spatial scales. The current study utilized a $200 \mu \mathrm{m}$ mesh to minimise clogging and abundance values were adjusted to account for the different volumes of water filtered in each trawl. While the $200 \mu \mathrm{m}$ mesh made the exclusion of smaller larvae $(<200 \mu \mathrm{m})$ unavoidable, the differences in community structure highlighted by the species retained in the nets were sufficient to consistently distinguish between populations from reserve, bay and coast areas. Coast and bay samples in spring were dominated by a few highly abundant species, illustrated by the lower species 


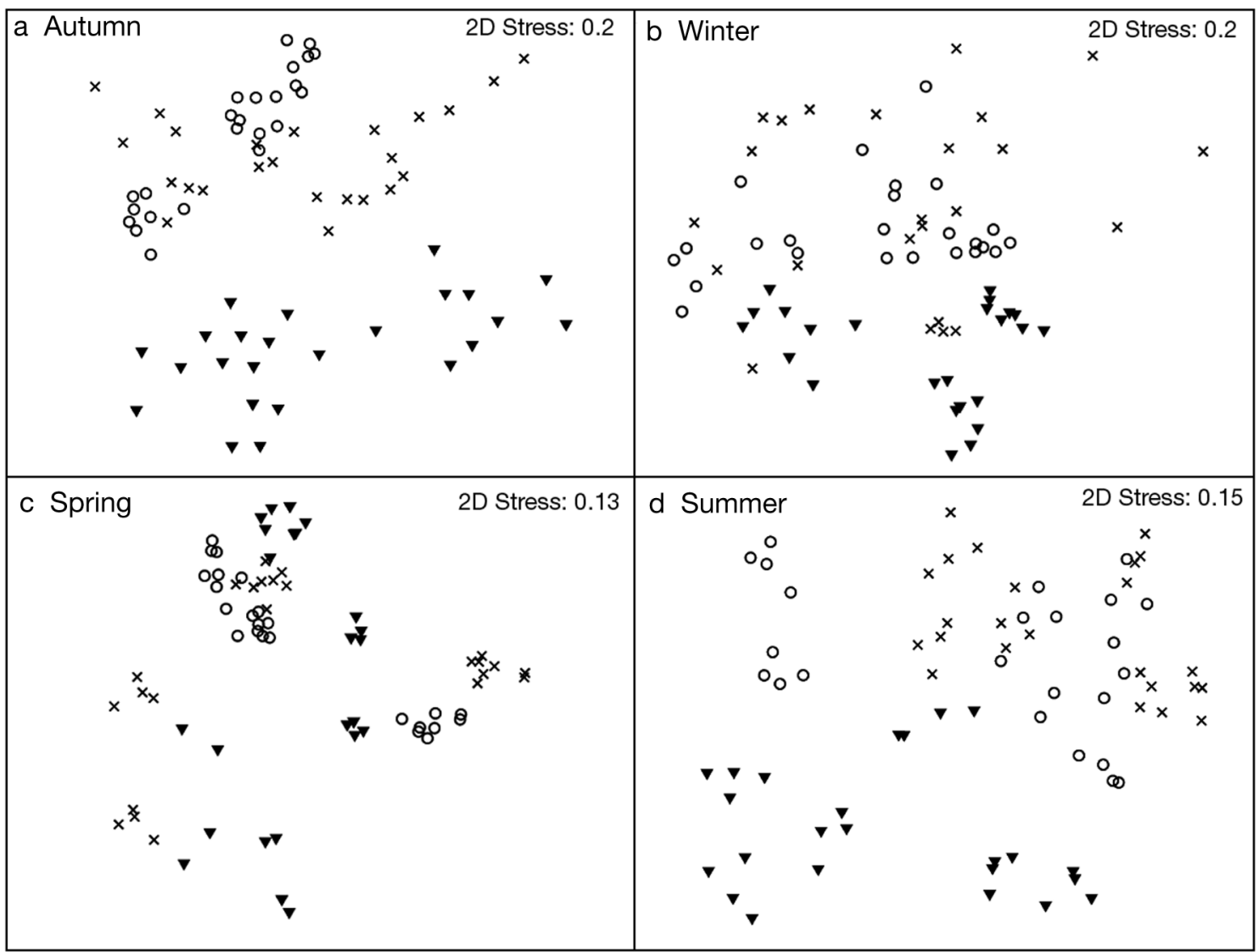

Fig. 3. Non-metric multidimensional scaling plots based on Bray-Curtis similarity using square-root transformed abundance data in (a) autumn, (b) winter, (c) spring, (d) summer. $O$ coast; $\nabla$ reserve; $\times$ bays

Table 2. Comparisons of larval assemblages in bay, ocean and reserve areas using non-parametric permutational multivariate analysis of variance (PERMANOVA) on square root transformed abundance. Area is a fixed factor with 3 levels: bays, coast and reserve. Season is a fixed orthogonal factor with 4 levels: autumn, winter, spring and summer. A posteriori pairwise comparisons with Bonferroni correction for multiple comparisons (reduced $\propto=0.0042$ ) showed significant differences between all areas within seasons $(p<0.004)$ except bays vs. coast samples in spring ( $p=0.005$; not significant)

\begin{tabular}{|lrcrc|}
\hline Source of variation & df & MS & \multicolumn{1}{c|}{$F$} & p \\
\hline Season & 3 & 68021.5506 & 6.2991 & $<0.0005$ \\
Area & 2 & 24789.8991 & 35.6229 & $<0.0005$ \\
Season $\times$ Area & 6 & 10798.6234 & 15.5175 & $<0.0005$ \\
Residual & 252 & 695.898 & & \\
Total & 287 & & & \\
\hline
\end{tabular}

diversity in spring than in summer and autumn samples (Table 1), and may have resulted from net clogging. Despite the overall trend for lower diversity in spring, reserve samples still had significantly higher diversity than bay and coast samples in this season (Table 1), and may have experienced less net clogging.
Assemblages in bay and coast samples were therefore more similar in species composition, clustering together on the MDS plot while reserve assemblages remained distinct (Fig. 3c).

In a similar study on the neuston community within Lough Hyne, no significant spatial or temporal differences in abundance at the monthly scale were detected (Rawlinson et al. 2005). This may have been caused by net clogging, as total filtration efficiency of nets was assumed, and differential clogging between areas and sampling times would lead to an inability to correct abundance for the volume of water sampled. In fact, other previous studies on plankton communities at Lough Hyne using towed nets have also assumed total filtration efficiency (Ballard \& Myers 2000, Greenwood et al. 2001), such that care must be taken when interpreting spatial and temporal patterns in abundance.

Large-scale transport processes such as upwelling (Roughgarden et al. 1988), local wind patterns (Shanks 1998), and smaller scale processes such as larval behaviour (Enright 1977, DiBacco \& Chadwick 2001) play an important role in dispersing larvae and de- 
Table 3. Results of SIMPER analysis using Bray-Curtis similarities on square root transformed abundance data for autumn, winter, spring and summer. Species representative of bays, reserve and coast areas are listed in order of their contribution (\%) to Bray-Curtis similarity between samples within each area. Average similarity (Av. sim.) denotes how similar all samples are to one another within each area

\begin{tabular}{|c|c|c|c|c|}
\hline & Autumn & Winter & Spring & Summer \\
\hline Bays & $\begin{array}{l}\text { Hiatella spp. } \\
\text { L. Littorea } \\
\text { Mytilus spp. } \\
\text { Ophiuroid } \\
\text { E. pilosa } \\
\text { V. stroemia } \\
\text { Cyprid } \\
\text { E. pilosa }\end{array}$ & $\begin{array}{l}\text { Spionidae } \\
\text { E. pilosa } \\
\text { Mytilus spp. } \\
\text { C. maenas } \\
\text { Hiatella spp. } \\
\text { V. stroemia } \\
\text { E. modestus }\end{array}$ & $\begin{array}{c}\text { V. stroemia } \\
\text { E. pilosa } \\
\text { Cyprid } \\
\text { E. modestus } \\
\text { Spionidae } \\
\text { L. Littorea } \\
\text { S. balanoides } \\
\text { M. membranacea } \\
\text { Cyprid }\end{array}$ & $\begin{array}{c}\text { C. stellatus } \\
\text { Mytilus spp. } \\
\text { L. Littorea } \\
\text { Hiatella spp. } \\
\text { E. pilosa } \\
\text { M. membranacea } \\
\text { V. stroemia } \\
\text { E. modestus }\end{array}$ \\
\hline Av. sim. & 53.98 & 25.14 & 37.01 & 57.20 \\
\hline Reserve & $\begin{array}{l}\text { L. Littorea } \\
\text { Mytilus spp. } \\
\text { E. modestus } \\
\text { Hiatella spp. } \\
\text { C. stellatus } \\
\text { V. stroemia } \\
\text { N. puber }\end{array}$ & $\begin{array}{l}\text { E. modestus } \\
\text { L. Littorea } \\
\text { V. stroemia } \\
\text { Spionidae } \\
\text { Mytilus spp. } \\
\text { C. stellatus } \\
\text { Hiatella spp. }\end{array}$ & $\begin{array}{l}\text { V. stroemia } \\
\text { L. Littorea } \\
\text { E. modestus } \\
\text { E. pilosa } \\
\text { Spionidae } \\
\text { N. puber } \\
\text { S. balanoides } \\
\text { P. hirtellus } \\
\text { N. puber }\end{array}$ & $\begin{array}{l}\text { L. Littorea } \\
\text { C. stellatus } \\
\text { Mytilus spp. } \\
\text { P. hirtellus } \\
\text { A. pespelicani } \\
\text { E. pilosa } \\
\text { E. modestus } \\
\text { V. stroemia }\end{array}$ \\
\hline Av. sim. & 47.57 & 39.84 & 40.41 & 53.52 \\
\hline Av. sim. & $\begin{array}{l}\text { Hiatella spp. } \\
\text { Mytilus spp. } \\
\text { L. Littorea } \\
\text { E. pilosa } \\
\text { Ophiuroid } \\
\text { V. stroemia } \\
\text { Cyprid }\end{array}$ & $\begin{array}{l}\text { E. pilosa } \\
\text { Spionidae } \\
\text { L. Littorea } \\
\text { C. stellatus } \\
\text { V. stroemia } \\
\text { Hiatella spp. }\end{array}$ & $\begin{array}{c}\text { V. stroemia } \\
\text { E. pilosa } \\
\text { L. Littorea } \\
\text { S. balanoides } \\
\text { Spionidae } \\
\text { Cyprid } \\
\text { M. membranacea } \\
\text { Mytilus spp. } \\
49.46\end{array}$ & $\begin{array}{c}\text { C. stellatus } \\
\text { L. Littorea } \\
\text { E. pilosa } \\
\text { Mytilus spp. } \\
\text { Hiatella spp. } \\
\text { M. membranacea } \\
\text { Cyprid } \\
\text { V. stroemia } \\
50.94\end{array}$ \\
\hline
\end{tabular}

coupling larval supply from local adult populations. However, the presence of nearshore fronts (McCulloch \& Shanks 2003, Shanks et al. 2003b), retention of water in bays (Gaines \& Bertness 1992) and behavioural responses of larvae (Kingsford et al. 2002) may play a contrasting role in retaining larvae locally. In fact, the effect even of large-scale processes such as upwelling and downwelling systems on larval distribution have been shown to vary with larval behaviour and vertical distribution (Shanks \& Brink 2005). This study compared larval assemblages in areas with differing water retention times, from open coastline to bays with relatively short (Tranabo and Tragumna, 0.89 and $1.86 \mathrm{~d}$ ) and long (Lough Hyne, 41 d) flushing times. Despite the relatively small spatial scale $(<3 \mathrm{~km})$ of this study, clear differences in larval assemblages occurred between areas throughout the year, although there was considerably more overlap between areas in winter and spring. This is not entirely surprising given seasonal changes in biological, meteorological and hydrographic conditions. Higher levels of net clogging during the spring plankton bloom result in a few highly abundant species dominating samples, and increased mixing as a result of winter storms can create more homogeneous assemblages throughout the region. Both factors would tend to increase the similarity between samples in the multivariate analysis giving the increased overlap observed in winter and spring samples.

Most species identified in the SIMPER analysis showed some temporal and spatial variability, making them useful for investigating larval retention in areas of differing 'openness'. Certain species tended to be representative of different areas, although this is not surprising given that larval supply will be related to local adult distribution. The consistently high larval abundance of Elminius modestus in the reserve is a case in point. The $41 \mathrm{~d}$ flushing time (Johnson et al. 1995) is certainly long enough for it to complete its entire larval duration of 17 to $34 \mathrm{~d}$ (Crisp 1958) inside the reserve boundaries where it has established itself as the dominant intertidal barnacle species (Lawson et al. 2004). However, despite the high abundance of E. modestus larvae in the reserve, quantification of lar- 


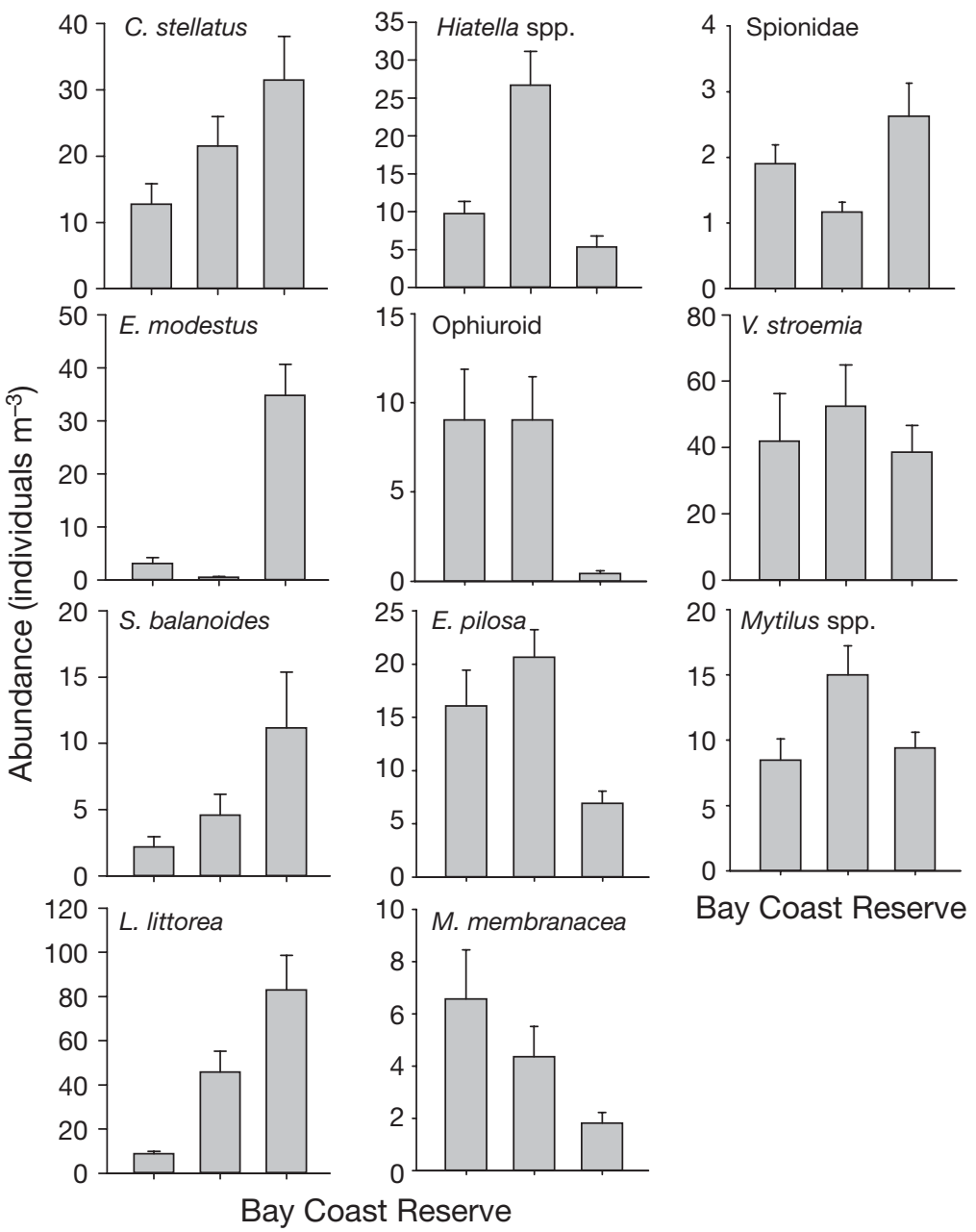

Fig. 4. Mean abundance \pm SE for 11 species identified as contributing the most to Bray-Curtis similarity (based on square-root transformed abundance data) between reserve, coast and bay samples. Note differences in scale

despite Chthamalus stellatus being a dominant barnacle species in the bays to the east of Lough Hyne, bay samples showed consistently lower larval abundance than reserve samples where $C$. stellatus is less abundant. This confirms that larval samples are not necessarily representative of local adult populations.

The distinct larval assemblages of the reserve compared to coast and bay assemblages throughout the year suggests that some mechanism is affecting larval dispersal patterns, providing further evidence that sites can become differentially connected to each other through advection of larvae, creating a spatially structured environment (Gaines et al. 2003). It is suggested that while water is retained in the bays to the east of the reserve, their relatively short flushing time is instrumental in promoting larval exchange between bay and adjacent open coast areas. This is further illustrated by the similarities in larval abundance in bay and coast samples for most of the species studied in Table 4, despite differences in adult distribution and abundance. The exceptionally long retention time of Lough Hyne water may result in increased larval retention, limiting exchange with the adjacent coastline, even given that the active advection of some larvae, particularly from estuarine systems has been recorded (DiBacco et al. 2001).

It is clear from the results that differences exist between univariate measures of communities and those obtained by

val abundance in flood and ebb tide samples taken from the tidal constriction found that this species was not exported from the reserve (M. J. Jessopp, unpubl. data). The increased settlement of the bryozoan Electra pilosa immediately outside the reserve (D. Watson, pers. comm.) suggests larger populations in these higher flow areas, and bryozoan larvae, including those of Membranipora membranacea, tended to be more abundant in coast and bay areas than in the reserve.

However, larval abundance did not consistently reflect known adult distribution patterns. Given that Littorina littorea is an intertidal species, and increased suitable habitat is available in reserve and bay than in coast areas, the higher abundance of larvae in the reserve is not unexpected. However, bay samples did not contain significantly higher abundance of this species than coast samples: coast samples actually had higher abundance than bays in summer. Additionally, multivariate analysis. Univariate ANOVA of diversity and abundance failed to detect many significant spatial and temporal differences, while the multivariate techniques were more sensitive in discriminating between sites and times, showing distinct larval assemblages throughout the year. In terms of future reserve designation and monitoring, it is clear that univariate techniques will be of limited use in detecting changes in communities, particularly following cessation of fishing activities and other disturbances after reserve designation.

Population sustainability in marine reserves requires either a large fraction of coastline designated as reserve, or individual reserves that are larger than the mean larval dispersal distances of the species intended to be protected (Botsford et al. 2001). While the results suggest that bays with a long retention time may effectively retain both short and long distance dispersers, this may have serious implications for population sustainability. 
Table 4. Analysis of variance (ANOVA) for species identified by SIMPER analysis as contributing to reserve, bay and coast area assemblages. Area is a fixed orthogonal factor with 3 levels; reserve, bay, coast. Season is a fixed orthogonal factor with 3 levels. Pairwise tests using Bonferroni correction for multiple comparisons are given below ANOVA results. Au: autumn; W: winter; Sp: spring; Su: summer; R: reserve; C: coast; B: bay

\begin{tabular}{|c|c|c|c|c|c|c|c|c|c|c|}
\hline Source of variation & $\mathrm{df}$ & MS & $F$ & $\mathrm{p}$ & MS & $F$ & $\mathrm{p}$ & MS & $F$ & $\mathrm{p}$ \\
\hline & & \multicolumn{3}{|c|}{ C. stellatus ${ }^{\mathrm{b}}$} & \multicolumn{3}{|c|}{ E. modestus ${ }^{\mathrm{a}, \mathrm{c}}$} & \multicolumn{3}{|c|}{$V$. stroemia ${ }^{\mathrm{b}}$} \\
\hline Area & 2 & 7.092 & 6.18 & 0.002 & 109.29 & 84.75 & $<0.001$ & 0.859 & 0.67 & 0.512 \\
\hline Season & 3 & 194.89 & 169.9 & $<0.001$ & 7.125 & 5.52 & 0.001 & 41.26 & 32.22 & $<0.001$ \\
\hline Area $\times$ Season & 6 & 1.718 & 1.5 & 0.179 & 1.807 & 1.4 & 0.214 & 3.071 & 2.4 & 0.028 \\
\hline Error & 276 & 1.147 & & & 1.29 & & & 1.281 & & \\
\hline \multirow[t]{2}{*}{ Total } & 287 & \multicolumn{3}{|c|}{$\mathrm{Sp}>\mathrm{Su}>\mathrm{Au}>\mathrm{W}$} & \multicolumn{3}{|c|}{$\begin{array}{c}\mathrm{R}>\mathrm{C}=\mathrm{B} \\
\mathrm{Sp}>\mathrm{Su}=\mathrm{Au}=\mathrm{W}\end{array}$} & \multicolumn{3}{|c|}{$\mathrm{Sp}>\mathrm{Su}=\mathrm{Au}=\mathrm{W}$} \\
\hline & & \multicolumn{3}{|c|}{ S. balanoides ${ }^{\mathrm{a}, \mathrm{b}}$} & \multicolumn{3}{|c|}{ Mytilus spp. ${ }^{\mathrm{b}}$} & \multicolumn{3}{|c|}{ Spionidae $^{\mathrm{b}}$} \\
\hline Area & 2 & 0.222 & 0.56 & 0.572 & 1.148 & $3.46^{1}$ & 0.033 & 0.2704 & 0.82 & 0.443 \\
\hline Season & 3 & 24.27 & 61.34 & $<0.001$ & 40.98 & 123.64 & $<0.001$ & 9.7508 & 29.46 & $<0.001$ \\
\hline Area $\times$ Season & 6 & 0.222 & 0.56 & 0.762 & 2.39 & 7.21 & $<0.001$ & 0.6905 & 2.09 & 0.055 \\
\hline Error & 276 & 0.396 & & & 0.331 & & & 0.3309 & & \\
\hline \multirow[t]{2}{*}{ Total } & 287 & \multicolumn{3}{|c|}{$\mathrm{Sp}>\mathrm{Su}=\mathrm{Au}=\mathrm{W}$} & \multicolumn{3}{|c|}{$\begin{array}{l}\text { Au: } R=B<C, W: R=C=B \\
\text { Sp: } R=C=B, S u: R=C=B\end{array}$} & \multicolumn{3}{|c|}{$\mathrm{Su}=\mathrm{Au}<\mathrm{Sp}=\mathrm{W}$} \\
\hline & & \multicolumn{3}{|c|}{ E. pilosa ${ }^{\mathrm{b}}$} & \multicolumn{3}{|c|}{ M. membranacea ${ }^{\mathrm{b}}$} & \multicolumn{3}{|c|}{ L. littore $\mathrm{a}^{\mathrm{a}, \mathrm{b}}$} \\
\hline Area & 2 & 13.26 & 24.53 & $<0.001$ & 1.880 & 3.93 & 0.021 & 30.53 & 66.33 & $<0.001$ \\
\hline Season & 3 & 14.33 & 26.5 & $<0.001$ & 18.40 & 38.45 & $<0.001$ & 47.02 & 102.17 & $<0.001$ \\
\hline Area $\times$ Season & 6 & 2.244 & 4.15 & 0.001 & 0.467 & 0.98 & 0.442 & 2.68 & 5.82 & $<0.001$ \\
\hline Error & 276 & 0.541 & & & 0.479 & & & 0.46 & & \\
\hline Total & 287 & \multicolumn{3}{|c|}{$\begin{array}{l}\text { Au: } R=B<C, W: R=C=B \\
\text { Sp: } R<C=B, S u: R=C=B\end{array}$} & \multicolumn{3}{|c|}{$\begin{array}{c}\mathrm{R}<\mathrm{C}=\mathrm{B} \\
\mathrm{Su}>\mathrm{Sp}>\mathrm{Au}>\mathrm{W}\end{array}$} & \multicolumn{3}{|c|}{$\begin{array}{l}\mathrm{Au}: \mathrm{R}=\mathrm{C}=\mathrm{B}, \mathrm{W}: \mathrm{R}>\mathrm{C}=\mathrm{B} \\
\mathrm{Sp}: \mathrm{R}=\mathrm{C}=\mathrm{B}, \mathrm{Su}: \mathrm{R}>\mathrm{C}>\mathrm{B}\end{array}$} \\
\hline & & \multicolumn{3}{|c|}{ Hiatella spp. ${ }^{\mathrm{a}, \mathrm{b}}$} & \multicolumn{3}{|c|}{ Ophiuroid ${ }^{\mathrm{a}, \mathrm{b}}$} & & & \\
\hline Area & 2 & 5.878 & 14 & $<0.001$ & 5.406 & 16.53 & $<0.001$ & & & \\
\hline Season & 3 & 58.429 & 139.2 & $<0.001$ & 30.56 & 93.41 & $<0.001$ & & & \\
\hline Area $\times$ Season & 6 & 3.836 & 9.14 & $<0.001$ & 3.016 & 9.22 & $<0.001$ & & & \\
\hline Error & 276 & 0.42 & & & 0.327 & & & & & \\
\hline Total & 287 & $\begin{array}{l}\mathrm{Au}: \mathrm{R} \\
\mathrm{Sp}: \mathrm{R}\end{array}$ & $\begin{array}{l}<\mathrm{B}<\mathrm{C}, \\
=\mathrm{C}=\mathrm{B},\end{array}$ & $\begin{array}{l}W: R=C=B \\
\text { Su: } R=C=B\end{array}$ & $\begin{array}{l}\mathrm{Au}: \mathrm{R} \\
\mathrm{Sp}: \mathrm{R}\end{array}$ & $\begin{array}{l}<C=B, \\
=C=B,\end{array}$ & $\begin{array}{l}\mathrm{V}: \mathrm{R}=\mathrm{C}=\mathrm{B} \\
\mathrm{U}: \mathrm{R}=\mathrm{C}=\mathrm{B}\end{array}$ & & & \\
\hline \multicolumn{11}{|c|}{$\begin{array}{l}\text { a Variance was heterogeneous (Bartlett's test } \mathrm{p}<0.05) \\
{ }^{\mathrm{b}} \text { Indicates } 4 \text { th root transformed abundance data } \\
{ }^{\mathrm{c}} \text { Indicates } \ln (x+1) \text { transformed abundance data }\end{array}$} \\
\hline
\end{tabular}

The limited exchange of larvae between the semi-enclosed reserve and adjacent coastline has created spatially distinct reserve assemblages, and may result in genetic isolation. Genetic isolation and reduced genetic diversity has already been demonstrated in a direct-developer, the dogwhelk Nucella lapillus in Lough Hyne (Bell \& Okamura 2005). Furthermore, if reserves are intended to act as a source of propagules to adjacent areas, bays with a large retention time will have minimal spillover effects to the surrounding coastline, and there is the possibility for failure of such reserves to recover from local catastrophes. Lough Hyne was designated as a reserve on the basis of historical and aesthetic factors and its likely failure as a reserve in terms of preserving representative local biodiversity, providing overspill of propagules to adjacent areas, or its ability to recover from local catastrophes only highlights the importance of understanding the underlying biological functioning of systems before designation of reserve areas.

Designating bays as reserve areas may provide a simple means of protecting species with both long and short dispersal distances, due to some degree of water and larval retention. However, many bays have considerable freshwater input and are subject to estuarine conditions that many species cannot tolerate. Fully marine bays such as those in the present study may not be common along many coastlines and as such are not a universal solution to the problem of reserve placement. Furthermore, to ensure effective reserve functioning, bays must be adequately 'connected' to the surrounding coastline to insure against the possibility of limited genetic differentiation and inbreeding. This raises the important question of how to determine the most appropriate bay configuration for a flushing time that allows some retention of larvae while at the same time being adequately connected to adjacent areas. The incorporation of population-level genetic diversity as an indicator of potential dispersal ability seems essential for any future studies involving the role of exposure and water retention times. This would increase our knowledge of reserve functioning to allow for the effective designation of future reserve areas. 
Acknowledgements. The authors thank R. Thomas and A. Dale for valuable assistance with fieldwork. This research was carried out in collaboration with T. Crowe of University College Dublin and M. Johnston and L. Allcock of Queens University Belfast under research permits 24/03, 08/04 and R.07.05 granted by D. O'Donnel and P. Graham of the Department of Environment, Heritage and Local Government. Funding was provided by the Irish Higher Education Authority North-South Cross-Borders Initiative, Strand 1, 2003. This manuscript was greatly improved by the comments of 3 anonymous referees.

\section{LITERATURE CITED}

Anderson MJ (2005) PERMANOVA: a FORTRAN computer program for permutational multivariate analysis of variance. Department of Statistics, University of Auckland, Auckland

Archambault P, Bourget E (1999) Influence of shoreline configuration on spatial variation of meroplanktonic larvae, recruitment and diversity of benthic subtidal communities. J Exp Mar Biol Ecol 241:309-333

Ballard L, Myers A (2000) Observations on the seasonal occurrence and abundance of gelatinous zooplankton in Lough Hyne, Co. Cork, south-west Ireland. Biol Environ Proc R Ir Acad B 100:75-83

Bell JJ, Okamura B (2005) Low genetic diversity in a marine nature reserve: re-evaluating diversity criteria in reserve design. Proc R Soc Lond B 272:1067-1074

Botsford LW, Hastings A, Gaines SD (2001) Dependence of sustainability on the configuration of marine reserves and larval dispersal distance. Ecol Lett 4:144-150

Caley MJ, Carr MH, Hixon MA, Hughes TP, Jones GP, Menge BA (1996) Recruitment and the local dynamics of open marine populations. Annu Rev Ecol Syst 27:477-500

Clarke KR, Warwick RM (2001) Change in marine communities: an approach to statistical analysis and interpretation. PRIMER-E, Plymouth

Crisp DJ (1958) The spread of Elminius-Modestus Darwin in north-west Europe. J Mar Biol Assoc UK 37:483-520

Delany J, Myers AA, McGrath D, O'Riordan RM, Power AM (2003) Role of post-settlement mortality and 'supply-side' ecology in setting patterns of intertidal distribution in the chthamalid barnacles Chthamalus montagui and C. stellatus. Mar Ecol Prog Ser 249:207-214

DiBacco C, Chadwick DB (2001) Assessing the dispersal and exchange of brachyuran larvae between regions of San Diego Bay, California and nearshore coastal habitats using elemental fingerprinting. J Mar Res 59:53-78

DiBacco C, Sutton D, McConnico L (2001) Vertical migration behavior and horizontal distribution of brachyuran larvae in a low-inflow estuary: implications for bay-ocean exchange. Mar Ecol Prog Ser 217:191-206

Enright JT (1977) Diurnal vertical migration — adaptive significance and timing. 1. Selective advantage-metabolic model. Limnol Oceanogr 22:856-872

Gaines SD, Bertness MD (1992) Dispersal of juveniles and variable recruitment in sessile marine species. Nature 360: $579-580$

Gaines SD, Gaylord B, Largier JL (2003) Avoiding current oversights in marine reserve design. Ecol Appl 13:S32-S46

Gell FR, Roberts CM (2003) Benefits beyond boundaries: the fishery effects of marine reserves. Trends Ecol Evol 18: 448-455

Gillibrand PA (2001) Calculating exchange times in a Scottish fjord using a 2-dimensional, laterally-integrated numerical model. Estuar Coast Shelf Sci 53:437-449

Greenwood A, O'Riordan RM, Barnes DKA (2001) Seasonality and vertical zonation of zooplankton in a semi-enclosed sea lough. J Mar Biol Assoc UK 81:213-220

Jenkins SR (2005) Larval habitat selection, not larval supply, determines settlement patterns and adult distribution in two chthamalid barnacles. J Anim Ecol 74:893-904

Johnson MP, Costello MJ, Odonnell D (1995) The nutrient economy of a marine inlet Lough-Hyne, south-west Ireland. Ophelia 41:137-151

Kaplan DM (2006) Alongshore advection and marine reserves: consequences for modelling and management. Mar Ecol Prog Ser 309:11-24

Kingsford MJ, Leis JM, Shanks A, Lindeman KC, Morgan SG, Pineda J (2002) Sensory environments, larval abilities and local self-recruitment. Bull Mar Sci 70:309-340

Kitching J (1987) Ecological studies at Lough Hyne. Adv Ecol Res 17:115-186

Lawson J, Davenport J, Whitaker A (2004) Barnacle distribution in Lough Hyne Marine Nature Reserve: a new baseline and an account of invasion by the introduced Australasian species Elminius modestus Darwin. Estuar Coast Shelf Sci 60:729-735

Lipcius RN, Stockhausen WT, Eggleston DB (2001) Marine reserves for Caribbean spiny lobster: empirical evaluation and theoretical metapopulation recruitment dynamics. Mar Freshw Res 52:1589-1598

Margalef R (1978) Sampling design: some examples. In: Sournia A (ed) Phytoplankton manual. Monographs on Oceanographic Methodology 6. UNESCO, Paris, p 17-31

McCulloch A, Shanks AL (2003) Topographically generated fronts, very nearshore oceanography and the distribution and settlement of mussel larvae and barnacle cyprids. J Plankton Res 25:1427-1439

Rawlinson KA, Davenport J, Barnes DKA (2004) Vertical migration strategies with respect to advection and stratification in a semi-enclosed lough: a comparison of meroand holozooplankton. Mar Biol 144:935-946

Rawlinson KA, Davenport JD, Barnes DKA (2005) Temporal variation in diversity and community structure of a semiisolated neuston community. Biol Environ Proc R Ir Acad B 105:107-122

Roughgarden J, Gaines S, Possingham H (1988) Recruitment dynamics in complex life-cycles. Science 241:1460-1466

Scheltema RS (1986) Long-distance dispersal by planktonic larvae of shoal-water benthic invertebrates among central Pacific islands. Bull Mar Sci 39:241-256

Shanks A, Brink L (2005) Upwelling, downwelling, and crossshelf transport of bivalve larvae: test of a hypothesis. Mar Ecol Prog Ser 302:1-12

Shanks AL (1998) Abundance of post-larval Callinectes sapidus, Penaeus spp., Uca spp. and Libinia spp. collected at an outer coastal site and their cross-shelf transport. Mar Ecol Prog Ser 168:57-69

Shanks AL, Grantham BA, Carr MH (2003a) Propagule dispersal distance and the size and spacing of marine reserves. Ecol Appl 13:S159-S169

Shanks AL, McCulloch A, Miller J (2003b) Topographically generated fronts, very nearshore oceanography and the distribution of larval invertebrates and holoplankters. J Plankton Res 25:1251-1277

Thorson G (1946) Reproduction and larval development of Danish marine bottom invertebrates. C. A. Reitzels Forlag, Copenhagen

Underwood AJ, Fairweather PG (1989) Supply-side ecology and benthic marine assemblages. Trends Ecol Evol 4: $16-20$

Submitted: April 10, 2006; Accepted: August 4, 2006

Proofs received from author(s): February 23, 2007 